\title{
Kasus Infestasi Endoparasit pada Kerbau (Bubalus bubalis) di Kecamatan Praya Barat Kabupaten Lombok Tengah
}

\section{(Endoparasitic Infestation Case on Buffalo (Bubalus bubalis) in West Praya District of Central Lombok)}

\author{
Muhammad Hipzul Mursyid', Anwar Rosyidi'2, Wayan Wariata², Made Sriasih ${ }^{2}$ \\ ${ }^{1}$ Alumni Fak Peternakan dan staf pada Fak. Kedokteran Universitas Mataram \\ ${ }^{2}$ Dosen Fakultas Peternakan Universitas Mataram \\ J1. Majapahit No. 62, Mataram 83125, NTB, Indonesia \\ Email: hipzulmuhammad999@gmail.com
}

Diterima: 5 Maret 2020/Disetujui: 19 Mei 2020

\begin{abstract}
ABSTRAK
Tujuan dari penelitian ini adalah untuk mengetahui infestasi endoparasit pada kerbau di Kecamatan Praya Barat, Lombok Tengah. Sampel feses diambil dari 61 ekor kerbau yang berasal dari 5 desa di kecamatan Praya Barat dan diperiksa di Laboratorium Dinas Peternakan dan Kesehatan Hewan Provinsi NTB, Banyumulek menggunakan metode apung dan sedimentasi untuk mendeteksi keberadaan dari telur parasit. Data yang diperoleh dianalisis secara deskriptif. Hasil penelitian menunjukan bahwa, dari 61 sampel yang diperiksa, 20 sampel $(32,7 \%)$ positif terinfeksi endoparasit dengan jenis infeksi tunggal dan multispesies. Sebanyak 13 sampel $(21,3 \%)$ terinfeksi Nematoda, 2 sampel $(3,27 \%)$ terinfeksi Cestoda, 2 sampel $(3,27 \%)$ terinfeksi Trematoda dan 11 sampel (18,03\%) terinfeksi Protozoa. Derajat infeksi endoparasit pada kerbau di Kecamatan Praya Barat termasuk kategori infeksi ringan. Jenis endoparasit yang menginfeksi kerbau di kecamatan Praya Barat adalah berasal dari family Toxocaridae, Trichostrongylidae, Cooperidae, Anoplocephalidae, Strongylidae, Strongyloididae, Chabertidae, Fasciolidae dan Eimeriidae. Prevalensi tertinggi untuk jenis cacing yaitu Toxocaridae dengan 11,46\%, sementara untuk protozoa yaitu Eimeriidae dengan persentase sebesar $18,01 \%$.
\end{abstract}

Kata kunci: Prevalensi, endoparasit, kerbau, Lombok Tengah

\begin{abstract}
The purpose of this study was to determine endoparasitic infestation on Buffaloes in Praya Barat district, Central Lombok. Stools samples were taken from 61 buffaloes from 5 villages and examined at Banyumulek Animal Health Laboratory of Animal Husbandry and Animal Health Service of NTB Province using the floating and sedimentation methods to perceive the presence of parasitic eggs. The data obtained were analyzed descriptively. The results show that from 61 fecal samples analyzed, 20 samples (32.7\%) were positively infected with endoparasites with a single type of infection and multi-species infection. A total of 13 samples $(21.3 \%)$ were infected with Nematodes, 2 samples $(3.27 \%)$ were infected with Cestode, 2 samples $(3.27 \%)$ were infected with Trematode and 11 samples $(18.03 \%)$ were infected with Protozoa. The degree of endoparasitic infection in buffaloes in West Praya district is included in the category of mild infection. Endoparasites that infect buffaloes in Praya Barat are coming from family Toxocaridae, Trichostrongylidae, Cooperidae, Anoplocephalidae, Strongylidae, Strongyloididae, Chabertidae, Fasciolidae and Eimeriidae. The highest prevalence for worm parasite was Toxocaridae with the percentage of $11.46 \%$, whilst for the protozoa was the family of Eimeriidae accounted for $18.01 \%$.
\end{abstract}

Keywords: Prevalence, Endoparasites, Buffalo, Central Lombok 


\section{PENDAHULUAN}

Selain sapi, ruminansia besar penghasil protein hewani adalah dari ternak kerbau. Populasi kerbau di Indonesia 95\% adalah kerbau lumpur (Alfiyati dan Fauziah, 2010), sedangkan di Nusa Tenggara Barat (NTB) merupakan salah satu provinsi di Indonesia yang memiliki populasi kerbau dengan jumlah populasi kerbau pada tahun 2016 adalah 121.572 ekor (Badan Pusat Statistik, 2020).

Lombok Tengah adalah salah satu kabupaten di provinsi NTB yang memiliki populasi kerbau yang cukup tinggi. Berdasarkan data yang dikeluarkan oleh Badan Pusat Statistik (2020) menyebutkan bahwa populasi kerbau di Kabupaten Lombok Tengah sebesar 21.545 ekor ternak, dengan populasi kerbau terbanyak salah satunya terdapat di kecamatan Praya Barat sejumlah 3.951 ekor.

Kerbau adalah salah satu jenis ternak ruminansia yang banyak ditemukan di Indonesia. Kerbau berasal dari sub family Bovidae yang terdiri atas kerbau domestik dan kerbau liar. Menurut Hasinah dan Handiwirawan (2006), pembagian dari kerbau domestik itu sendiri dibagi menjadi dua kelompok yaitu kerbau sungai (River buffalo) dan kerbau lumpur (Swamp buffalo), sedangkan kerbau liar dibagi menjadi tamaraw (Bubalus. mindorensis), anoa (Bubalus. depressicornis) dan kerbau Afrika (Buballus caffer).

Sama halnya dengan ternak ruminansia yang lainnya, kerbau juga tidak bisa dilepaskan dari berbagai gangguan penyakit yang dapat menyebabkan penurunan produktivitas dari ternak itu sendiri. Penyakit yang dapat mengganggu ternak kerbau tersebut dapat berupa infeksi bakteri, virus maupun infeksi parasitik seperti cacing dan protozoa (endoparasit) (Tarmudji, 1990). Infeksi endoparasit dapat mengakibatkan penurunan produktivitas diantaranya penurunan bobot badan dan pertumbuhan yang lambat, sehingga merugikan peternak (Dorny et al. 2011)

Endoparasit adalah salah satu jenis pengklasifikasian parasit yang hidup di dalam tubuh organisme. Jenis endoparasit yang ada antara lain cacing dan protozoa. Endoparasit dalam tubuh suatu organism terdapat pada berbagai sistem di dalam tubuh inang seperti sistem pencernaan dan lain sebagainya.

Informasi kejadian infeksien doparasit pada kerbau di NTB masih sedikit. Untuk itu perlu dilakukan penelitian guna mendapatkan data dasa rmengenai jenis endoparasit dan prevalensi infeksinya pada kerbau. Data dasar tersebut diperlukan sebagai acuan untuk menyusun program pengendalian infeksi parasitik pada kerbau di NTB.

Berdasarkan latar belakang di atas, maka rumusan masalah dari penelitian ini adalah apakah terdapat kejadian infeksi endoparasit pada kerbau di Kecamatan Praya Barat Kabupaten Lombok Tengah.

\section{MATERI DAN METODE}

\section{Waktu dan Tempat Penelitian}

Penelitian ini dilaksanakan pada bulan Juni sampai dengan Juli 2019, 
bertempat di peternakan rakyat

Kecamatan Praya Barat Kabupaten Lombok Tengah Nusa Tenggara Barat. Kemudian penelitian ini dilanjutkan dengan pemeriksaan endoparasit di Laboratorium Dinas Peternakan dan Kesehatan Hewan Provinsi NTB, Banyumulek.

\section{Alat dan BahanPenelitian}

Adapun alat yang digunakan pada penelitian ini adalah: timbangan analitik, mikroskop, cover glass, deck glass, Object glass, slide kamar penghitung telur cacing, cawan porselen, mortar, silinder pencampur $100 \mathrm{cc}$, alat pengaduk tinja, stik untuk mencampur feses, saringan, pipet Pasteur, tisu, beaker glass, lemari pendingin, kantung plastik, kertas label, sarung tangan, alat tulis, kamera dan lembar kuesioner. Bahan yang digunakan dalam penelitian ini adalah feses kerbau lumpur segar, larutan garam jenuh dan Methylen Blue 0,1\%.

\section{Metode Penelitian}

Penelitian ini menggunakan metode deskriptif yang diterapkan dengan metode survey dengan pengambilan sampel pada 5 desa dari 10 desa yang ada di Kecamatan Praya Barat yang memiliki populasi kerbau terbanyak. Jumlah sampel ternak yang digunakan, ditentukan dengan asumsi prevalensi sebesar 19\% yang didapatkan dari metode trial and error dengan tingkat konfidensi sebesar 95\% menggunakan rumus Selvin (2004) berikut:

$$
\begin{aligned}
n & =\frac{4 P(1-P)}{\mathrm{L}^{2}} \\
& =\frac{4 \times 0.19(1-0.19)}{0.1^{2}}
\end{aligned}
$$

$=60.8$ dibulatkan menjadi 61 sampel

Keterangan:

$\mathrm{n}=$ Jumlah sampel yang diambil

$\mathrm{P}=$ Asumsi prevalensi $(19 \%)$

$\mathrm{L}=$ Tingkat kesalahan $10 \%(0.1)$

\section{Metode Pemeriksaan Telur Cacing Metode Apung}

Menimbang feses sebanyak 3 gram, selanjutnya dimasukkan ke dalam cawan porselen dan ditambahkan $10 \mathrm{ml}$ air. Kemudian campuran feses dan air tersebut digerus menggunakan mortar dan kemudian diaduk dengan stik hingga homogen. Selanjutnya menuangkan feses yang telah homogeny tersebut ke dalam silinder pencampur yang berisi larutan garam jenuh sebanyak $50 \mathrm{cc}$. kemudian larutan tersebut diaduk secara melingkar dan selanjutnya disaring. Kemudian didiamkan selama 5 menit agar terbentuk supernatant dan endapan. Terakhir, mengambil supernatant secukupnya dengan pipet Pasteur lalu dimasukkan ke dalam kamar hitung dan dilakukan pengamatan di bawah mikroskop perbesaran 100 kali.

\section{Metode Sedimentasi}

Menimbang feses sebanyak 3 gram, selanjutnya dimasukkan ke dalam tabung dan ditambahkan air hingga $50 \mathrm{ml}$, kemudian diaduk hingga homogen. Kemudian menyaring suspense dan masukkan ke dalam tabung kerucut kemudian menambahkan air hingga penuh. Kemudian endapkan larutan sampel selama lima menit, kemudian supernatannya dibuang. Selanjutnya 
menambahkan air bersih kembali sampai $50 \mathrm{cc}$ ke dalam endapan, kemudian diaduk dan diendapkan kembali selama 6 menit. Setelah 6 menit, supernatannya dibuang kembali dan sisakan endapan sebanyak 5 cc dan diulangi sebanyak 3 kali. Selanjutnya, menambahkan 2 teteslarutan Methylen blue $0,1 \%$ ke dalam endapan. Kemudian diaduk hingga merata dengan menggunakan pipet, selanjutnya larutan tersebut dimasukkan ke dalam kamar hitung dan melakukan pengamatan di bawah mikroskop perbesaran 100 kali.

\section{Analisis Data}

1. Data yang digunakan pada penelitian ini disajikan dalam bentuk gambar serta jenis parasit yang ditemukan.

2. Data yang diperoleh dianalisis secara deskriptif. Untuk menghitung prevalensi digunakan rumus menurut Soulsby (1982) sebagai berikut:
Prevalensi

$=\frac{\text { Jumlah kerbau yang terinfeksi parasit }}{\text { Jumlah sampel kerbau yang diperiksa }} \times 100 \%$

\section{HASIL DAN PEMBAHASAN}

Tingkat Prevalensi Endoparasit pada Kerbau di Kecamatan Praya Barat

Jenis endoparasit telur cacing yang ditemukan berdasarkan pemeriksaan mikroskopis dengan metode apung dan sedimentasi adalah Toxocaridae, Trichostrongylidae, Cooperiidae, Anoplocephalidae, Strongylidae, Strongyloididae, Chabertiidae dan Fasciolidae. Sementara untuk jenis protozoa yang ditemukan adalah Eimeriidae. Adapun hasil uji laboratorium yang telah didapatkan positif mengandung parasit dapat dilihat pada Tabel 1 berikut ini: 
Tabel 1. Hasil pemeriksaan endoparasit dengan metode apung dan sedimentasi pada kerbau di Kecamatan Praya Barat

\begin{tabular}{|c|c|c|c|c|c|}
\hline \multirow{2}{*}{ No. } & \multirow{2}{*}{ Kode } & \multicolumn{4}{|c|}{ Hasil Pengujian Endoparasit } \\
\hline & & Nematoda & Cestoda & Trematoda & Protozoa \\
\hline 1. & $\mathrm{~K} 7 \mathrm{~S}$ & & & & Eimeriidae +100 \\
\hline 2. & K11S & Toxocaridae +150 & & & Eimeriidae +500 \\
\hline 3. & K12S & & & & Eimeriidae +100 \\
\hline 4. & $\mathrm{~K} 15 \mathrm{~S}$ & & & $\begin{array}{l}\text { Fasciolidae } \\
+7\end{array}$ & \\
\hline 5. & $\mathrm{~K} 16 \mathrm{~S}$ & Toxocaridae +100 & & & \\
\hline 6. & K17S & Toxocaridae +100 & Anoplocephalidae +50 & & \\
\hline 7. & $\mathrm{~K} 18 \mathrm{~S}$ & Toxocaridae +200 & Anoplocephalidae +50 & & \\
\hline 8. & K19S & Toxocaridae +50 & & & \\
\hline 9. & K20S & Toxocaridae +240 & & & Eimeriidae +81 \\
\hline 10. & K26J & & & $\begin{array}{c}\text { Fasciolidae } \\
+7\end{array}$ & \\
\hline 11. & K29J & Trichostrongylide +50 & & & \\
\hline 12. & $\mathrm{~K} 31 \mathrm{~J}$ & $\begin{array}{c}\text { Trichostrongylide } \\
+50, \text { Cooperiidae }+50\end{array}$ & & & Eimeriidae +50 \\
\hline 13. & $\mathrm{~K} 34 \mathrm{~J}$ & & & & Eimeriidae +50 \\
\hline 14. & K38B & Toxocaridae +50 & & & \\
\hline 15. & K40B & Strongyloididae +200 & & & \\
\hline 16. & $\mathrm{~K} 43 \mathrm{M}$ & Strongylidae +50 & & & Eimeriidae +400 \\
\hline 17. & K46M & & & & Eimeriidae +50 \\
\hline 18. & K47M & & & & Eimeriidae +50 \\
\hline 19. & $\mathrm{~K} 52 \mathrm{M}$ & Chabertiidae +50 & & & Eimeriidae +100 \\
\hline 20. & $\mathrm{~K} 53 \mathrm{M}$ & & & & Eimeriidae +1000 \\
\hline & mlah & $21,3 \%$ & $3,27 \%$ & $3,27 \%$ & $18,03 \%$ \\
\hline
\end{tabular}

Keterangan:

1. Kode sampel dengan akhiran huruf S, berasal dari desa Selong Belanak

2. Kode sampel dengan akhiran huruf J, berasal dari desa Batu Jai

3. Kode sampel dengan akhiran huruf $B$, berasal dari desa Bonder

4. Kode sampel dengan akhiran huruf $\mathrm{M}$, berasal dari desa Mekarsari

Hasil pemeriksaan mikroskopik menunjukkan bahwa dari 61 sampel feses kerbau yang diperiksa, 20 (32,7\%) sampel terinfeksi parasit, dengan rincian sampel terinfeksi Nematoda: $13 \quad(21,3 \%)$, Cestoda: 2 (3,27\%), Trematoda: 2 (3,27\%) dan protozoa: 11 (18,03\%). Prevalensi endoparasit untuk jenis parasit cacing pada penelitian ini lebih tinggi jika dibandingkan penelitian yang telah dilakukan oleh Padondan (2016) pada kerbau di Kabupaten Toraja, yang menyebutkan infeksi parasit cacing sebesar 10,7\%. Kemudian untuk prevalensi infeksi endoparasit jenis parasit protozoa pada penelitian ini lebih tinggi jika dibandingkan dengan penelitian yang dilakukan oleh Tolistiawaty dkk (2016) pada ternak ruminansia di Kabupaten Sigi, Sulawesi Tengah yang menyebutkan 
infeksi parasit protozoa sebesar 3,1\%. Namun, hasil penelitian Sriasit et al. (2018) menunjukkan bahwa protozoa (Coccidia) merupakan parasit yang banyak ditemukan (23.68\%) pada sapi Bali $(\mathrm{n}=76)$ yang dipelihara secara semiintensif.

\section{Tingkat Prevalensi Endoparasit Berdasarkan Infeksi Tunggal dan Multispesies}

Hasil penelitian menunjukkan bahwa terjadinya infeksi tunggal dan infeksi multispesies pada pemeriksaan mikroskopis sampel feses kerbau. Infeksi multispesies telur parasit yang ditemukan adalah Toxocaridae dengan Eimeriidae Toxocaridae dengan Anoplocephalidae; Toxocaridae, Cooperidae dengan Eimeriidae; Strongylidae dengan Eimeriidae; dan Chabertiidae dengan Eimeriidae. Sedangkan untuk infeksi tunggal telur parasit adalah Eimeridae, Fasciolidae, Toxocaridae, Trichostrongylidae dan Strongyloididae. Infeksi tunggal tingkat prevalensinya lebih tinggi sebesar 21,27\% dibanding dengan infeksi multispesies yaitu sebesar 11,43\% (Tabel 2).

Tabel 2. Prevalensi infeksi tunggal dan multispesies endoparasit pada kerbau di Kecamatan Praya Barat

\begin{tabular}{ccccc}
\hline No. & Jenis Infeksi & $\begin{array}{c}\text { Jumlah Sampel } \\
\text { yang Terinfeksi }\end{array}$ & $\begin{array}{c}\text { Jumlah } \\
\text { Sampel }\end{array}$ & Prevalensi (\%) \\
\hline 1 & Toxocaridae + Eimeriidae & 2 & 61 & 3,27 \\
2 & Toxocaridae + Anoplocephalidae & 2 & 61 & 3,27 \\
3 & Toxocaridae, Cooperiidae & 1 & 61 & 1,63 \\
4 & Eimeriidae & 1 & 61 & 1,63 \\
5 & Strongylidae + Eimeriidae & 1 & 61 & 1,63 \\
6 & Chabertidae + Eimeriidae & 6 & 61 & 9,83 \\
7 & Eimeridae & 2 & 61 & 3,27 \\
8 & Fasciolidae & 3 & 61 & 4,91 \\
9 & Toxocaridae & 1 & 61 & 1,63 \\
10 & Trichostrongylidae & 1 & 61 & 1,63 \\
\hline
\end{tabular}

Tingginya prevalensi infeksi tunggal dari parasit disebabkan serangan parasit umum terjadi pada hewan ternak. Infeksi yang terjadi pada hewan ternak tersebut diakibatkan oleh lemahnya ketahanan tubuh hewan dalam melawan serangan parasit (Soulsby, 1982). Menurut Levine (1994), infeksi multispesies atau tunggal sering terjadi pada ruminansia, sehingga sulit untuk mengetahui pengaruh khusus yang ditimbulkan. Infeksi yang terjadi biasanya dilakukan oleh bermacam-macam jenis cacing yang terjadi baik pada abomasum, usus dan organ lain, sehingga pengaruhnya berupa kombinasi atau campuran dari parasit yang ada.

\section{Infestasi Endopararasit pada Kerbau Per Desa di Kecamatan Praya Barat}

Berdasarkan hasil pemeriksaan, didapatkan data infeksi endoparasit pada kerbau di beberapa desa di Kecamatan 
Praya Barat. Informasi tersebut dapat dilihat pada Tabel 3.

Tabel 3. Infestasi endoparasit pada kerbau beberapa desa di Kecamatan Praya Barat

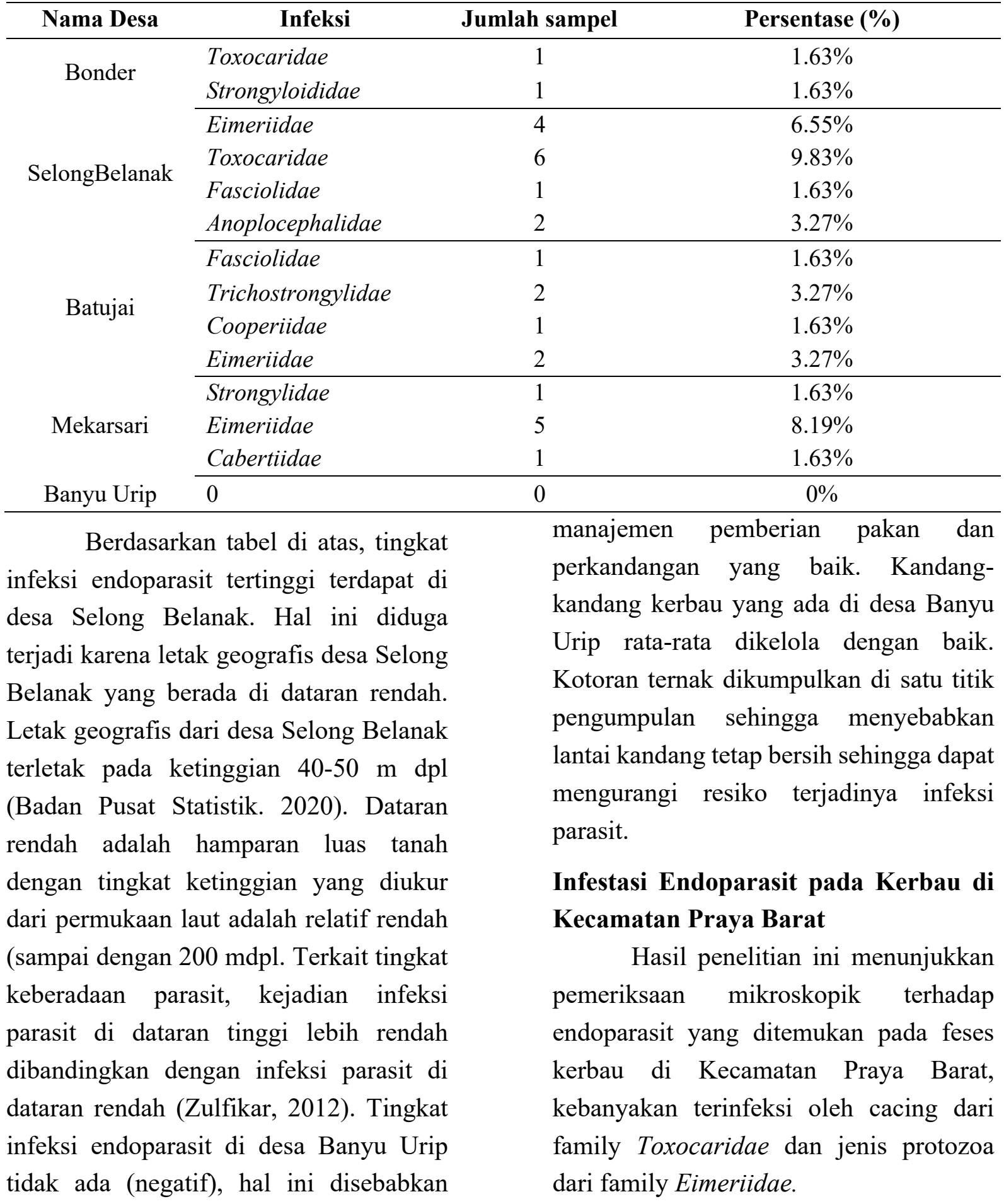


Tabel 4. Prevalensi infestasi parasit pada kerbau di Kecamatan Praya Barat

\begin{tabular}{ccccccccccc}
\hline \multirow{2}{*}{ No } & \multirow{2}{*}{ Desa } & \multicolumn{10}{c}{ Family Parasit } \\
\cline { 3 - 10 } & & TC & SD & OE & F & AN & TS & CP & CB & SL \\
\hline 1 & Bonder & $1.63 \%$ & $1.63 \%$ & $0 \%$ & $0 \%$ & $0 \%$ & $0 \%$ & $0 \%$ & $0 \%$ & $0 \%$ \\
2 & Selong B. & $9.83 \%$ & $0 \%$ & $6.55 \%$ & $1.63 \%$ & $3.27 \%$ & $0 \%$ & $0 \%$ & $0 \%$ & $0 \%$ \\
3 & Batujai & $0 \%$ & $0 \%$ & $3.27 \%$ & $1.63 \%$ & $0 \%$ & $3.27 \%$ & $1.63 \%$ & $0 \%$ & $0 \%$ \\
4 & Mekarsari & $0 \%$ & $0 \%$ & $8.19 \%$ & $0 \%$ & $0 \%$ & $0 \%$ & $0 \%$ & $1.63 \%$ & $1.63 \%$ \\
5 & B. Urip & $0 \%$ & $0 \%$ & $0 \%$ & $0 \%$ & $0 \%$ & $0 \%$ & $0 \%$ & $0 \%$ & $0 \%$ \\
\hline \multicolumn{1}{l}{ Total } & $11,46 \%$ & $1.63 \%$ & $18.01 \%$ & $3.26 \%$ & $3.27 \%$ & $3.27 \%$ & $1.63 \%$ & $1.63 \%$ & $1.63 \%$ \\
\hline
\end{tabular}

Keterangan:

$\mathrm{TC}=$ Toxocaridae $; \mathrm{SD}=$ Strongyloididae $; \mathrm{OE}=$ Eimeriidae $; \mathrm{F}=$ Fasciolidae $; \mathrm{AN}=$ Anoplocephalidae $\mathrm{TS}=$ Trichostrongylidae $; \mathrm{CP}=$ Cooperiidae $; \mathrm{CB}=$ Cabertiidae $; \mathrm{SL}=$ Strongylidae

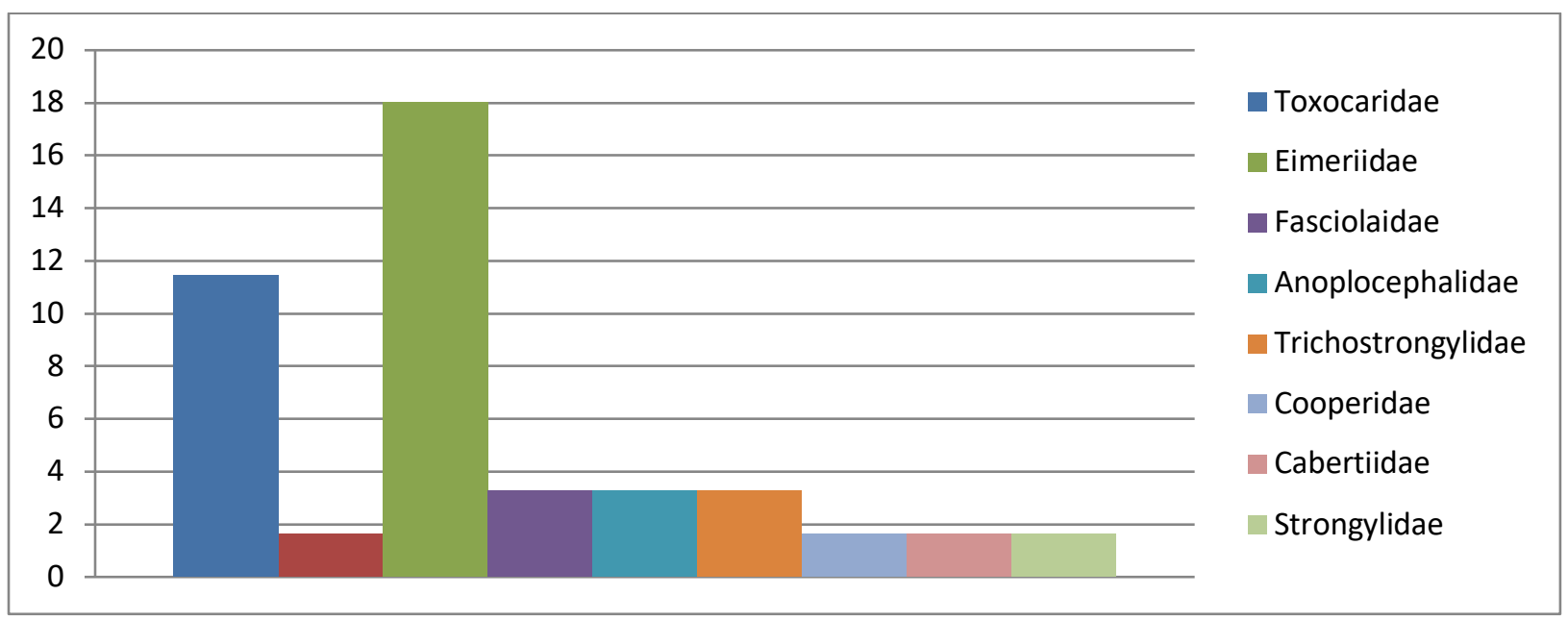

Gambar 1. Diferensiasi jenis endoparasit pada kerbau di Kecamatan Praya Barat

Jenis endoparasit pada kerbau yang terinfeksi di Kecamatan Praya Barat, teramati bahwa jenis parasit cacing yang memiliki prevalensi tertinggi adalah Toxocaridae yaitu pada 11,46\% (Gambar 1). Tingkat prevalensi ini lebih rendah jika dibandingkan dengan penelitian yang telah dilakukan oleh Bhutto et al. (2002) yang menyebutkan bahwa tingkat prevalensi Toxocaridae pada kerbau di kota Tandojam, Pakistan sebesar 33\%. Rendahnya tingkat prevalensi Toxocaridae di kecamatan Praya Barat ini disebabkan sampel yang digunakan pada penelitian ini rata - rata berusia di atas 5 tahun. Kejadian ini sesuai dengan penelitian yang dilakukan oleh Rian (2004) yang menyebutkan bahwa infeksi Toxocaridae pada kerbau dan sapi lebih banyak ditemukan pada anak kerbau dan anak sapi dari pada yang dewasa. Sedangkan untuk parasit jenis protozoa yang memiliki prevalensi tertinggi adalah family Eimeriidae yaitu 18,01\% (Gambar 1). Tingkat prevalensi ini hampir sama jika dibandingkan dengan penelitian yang dilakukan oleh Ulum (2017) yang melaporkan infeksi Eimeria spp. pada kerbau di daerah Ciapus Bogor sebesar 19,04\%. Hal ini terjadi karena tidak dipisahkannya kandang induk dan anaknya. Peternak yang masih 
menerapkan manajemen peternakan tradisional akan mengandangkan pedet dengan induknya dalam satu kandang yang sama, sehingga memungkinkan terjadinya penularan Eimeriidae semakin tinggi (Davoudi et al., 2011).

\section{Derajat Infeksi}

Berdasarkan penelitian yang telah dilakukan pada 5 desa yang telah diambil sampelnya, ditemukan 9 jenis parasit yang menginfeksi ternak Kerbau di kecamatan Praya Barat dengan jumlah telur yang memiliki interval beragam. Informasi tersebut dapat dilihat pada Tabel 6 .

Tabel 6. Derajat infeksi endoparasit pada kerbau per desa di Kecamatan Praya Barat

\begin{tabular}{|c|c|c|c|c|}
\hline No. & Nama Desa & Jenis Parasit & Interval epg & Derajat Infeksi \\
\hline \multirow{2}{*}{1} & \multirow{2}{*}{ Bonder } & Toxocaridae & 50 & Ringan \\
\hline & & Strongyloididae & 200 & Ringan \\
\hline \multirow{4}{*}{2} & \multirow{4}{*}{$\begin{array}{c}\text { Selong } \\
\text { Belanak }\end{array}$} & Eimeriidae & $81-500$ & Ringan \\
\hline & & Toxocaridae & $50-240$ & Ringan \\
\hline & & Fasciolidae & 7 & Ringan \\
\hline & & Anoplocephalidae & 50 & Ringan \\
\hline \multirow{4}{*}{3} & \multirow{4}{*}{ Batujai } & Fasciolidae & 7 & Ringan \\
\hline & & Trichostrongylidae & 50 & Ringan \\
\hline & & Cooperiidae & 50 & Ringan \\
\hline & & Eimeriidae & 5 & Ringan \\
\hline \multirow{3}{*}{4} & \multirow{3}{*}{ Mekarsari } & Strongylidae & 50 & Ringan \\
\hline & & Eimeriidae & $50-1000$ & Ringan \\
\hline & & Cabertiidae & 50 & Ringan \\
\hline 5 & Banyu Urip & Negatif & \multicolumn{2}{|r|}{ Negatif } \\
\hline \multirow{9}{*}{\multicolumn{3}{|c|}{$\begin{array}{l}\text { nematoda, maka derajat infeksi dapat } \\
\text { dibedakan menjadi infeksi ringan jika } \\
\text { jumlah telur 1-499 butir per gram; infeksi } \\
\text { sedang ditunjukkan jika jumlah telur } 500 \text { - } \\
5000 \text { butir per gram dan infeksi berat } \\
\text { ditunjukkan jika telur yang dihasilkan> } \\
5000 \text { butir per gram feses ternak } \\
\text { (Thienpont et al., 1995).Berdasarkan } \\
\text { standar tersebut, maka dapat dinyatakan } \\
\text { bahwa derajat infeksi Nematoda pada } \\
\text { ternak kerbau di Kecamatan Praya Barat } \\
\text { termasuk kategori derajat infeksi ringan. }\end{array}$}} & \multicolumn{2}{|c|}{$\begin{array}{l}20-50 \text { butir per gram feses, infeksi } \\
\text { sedang apabila jumlah telur yang } \\
\text { ditemukan antara } 10-25 \text { butir per gram } \\
\text { feses dan infeksi ringan apabila jumlah } \\
\text { telur yang ditemukan dibawah } 10 \text { butir per }\end{array}$} \\
\hline & & & \multirow{6}{*}{\multicolumn{2}{|c|}{$\begin{array}{l}\text { gram feses (Dirkeswan. 1998). } \\
\text { Berdasarkan standar derajat infeksi } \\
\text { fasciolidae tersebut, maka dapat } \\
\text { dinyatakan bahwa infeksi Trematoda pada } \\
\text { ternak kerbau di Kecamatan Praya Barat } \\
\text { termasuk kategori derajat infeksi ringan. }\end{array}$}} \\
\hline & & & & \\
\hline & & & & \\
\hline & & & & \\
\hline & & & & \\
\hline & & & & \\
\hline & & & \multirow{2}{*}{\multicolumn{2}{|c|}{$\begin{array}{l}\text { Menurut Whitlock (1980), standar } \\
\text { infeksi untuk parasit jenis Cestoda }\end{array}$}} \\
\hline & & & & \\
\hline $\begin{array}{l}\text { terma } \\
\text { jumla }\end{array}$ & $\begin{array}{l}\text { Infeksi telur } \\
\text { uk pada derajat } \\
\text { telur cacing ya }\end{array}$ & Infeksi telur cacing fasciolidae. & \multicolumn{2}{|c|}{$\begin{array}{l}\text { termasuk infeksi ringan jika telur cacing } \\
\text { yang ditemukan sebanyak } 40-500 \text { butir } \\
\text { per gram feses, infeksi sedang jika telur }\end{array}$} \\
\hline
\end{tabular}


cacing yang ditemukan sebanyak 5001000 butir per gram feses dan infeksi berat jika telur cacing yang ditemukan $>1000$ butir per gram feses. Berdasarkan standar derajat infeksi untuk parasit jenis Cestoda dan Coccidia tersebut, maka dapat dinyatakan bahwa infeksi Cestoda pada ternak kerbau di Kecamatan Praya Barat termasuk kategori derajat infeksi ringan.

Derajat infeksi koksidiosis dapat diklasifikasikan dalam tiga kelompok yaitu infeksi ringan yaitu jika ditemukan telur sebanyak 50 sampai 1.000 epg, infeksi sedang jika ditemukan telur sebanyak 1.000 sampai 5.000 epg dan infeksi tinggi jika ditemukan telur lebih dari 5.000 epg (Bangoura dan Daugschies, 2011). Berdasarkan standar derajat infeksi koksidiosis tersebut, maka dapat dinyatakan bahwa infeksi protozoa pada ternak kerbau di Kecamatan Praya Barat termasuk kategori derajat infeksi ringan.

\section{KESIMPULAN}

Berdasarkan hasil yang telah didapatkan, diketahui bahwa dari 61 sampel yang diperiksa, sebanyak 20 sampel positif terinfeksi endoparasit dengan jenis infeksi tunggal dan multispesies. Sebanyak $21,27 \%$ sampel termasuk dalam infeksi tunggal dan sebanyak $11,43 \%$ termasuk infeksi multispesies. Tingkat prevalensi infeksi endoparasit pada kerbau di Kecamatan Praya Barat adalah 32,7\%. Dari 61 sampel yang diperiksa, jenis parasit yang ditemukan adalah Nematoda 21,3\%, Cestoda $3,27 \%$, Trematoda $3,27 \%$ dan protozoa $18,03 \%$. Derajat infeksi endoparasit pada kerbau di Kecamatan
Praya Barat termasuk dalam kategori infeksi ringan. Tingkat prevalensi Toxocaridae adalah 11, 46\%, Strongyloididae 1,67\%, Fasciolidae 3,26\%, Anoplocephalidae 3,27\%, Trichostrongylidae 3,27\%, Cooperiidae 1,63\%, Cabertiidae 1,63\% Strongylidae 1,63 dan Eimeriidae sebesar 18,01\%.

\section{SARAN}

Perlu diberikan obat parasit secara rutin dan perbaikan manajemen pemeliharaan untuk mencegah infeksi endoparasit pada kerbau di kecamatan Praya Barat kabupaten Lombok Tengah.

Untuk peneliti selajutnya, agar memilih lokasi penelitian lainnya, sehingga data yang diperoleh dapat menjadi referensi peneliti lain dan menambah data terkait infestasi endoparasit di NTB.

\section{DAFTAR PUSTAKA}

Alfiyati A dan Fauziah. 2010. PengembanganPembibitanKerbau dalamUpayaMemenuhiKetersedia anDagingdalam Negeri.] http: // www. ditjennak. go. id/ buletin /art3. pdf . [Internet]. [diakses 16 Maret 2019].

Badan Pusat Statistik. 2020. Kecamatan Praya Barat Dalam Angka 2020. Kabupaten Lombok Tengah: Badan Pusat Statistik.

Bangoura B, dan Daugschies A. 2011. Parasitological and clinical parameters of experimental Eimeria zuernii infections in calves and influence on weight gain and haemogram. J Parasitol Res. 100: 1331-1340.

Bhutto B, Phullan MS, Rind R, Soomro AH. 2002. Prevalence of gastrointestinal helminths in buffalo calves. J Biol Sci. 2(1): 43-45 
Davoudi Y, Garedaghi Y, Nourmohammadzadeh F, Eftekhari Z, Safarmashaei S. 2011. Study on prevalence rate of coccidiosis in diarrheic calves in East Azerbaijan province. Adv Environ Biol. 5(7):1563-1565.

Dirkeswan.1998. Buku Pegangan dan Petunjuk Teknis Parasitologi. Laboratorium Kesehatan Hewan Dinas Peternakan Provinsi Nusa Tenggara Barat. Mataram: Dinas Peternakan dan Kesehatan Hewan.

Dorny P, Valerie S, Johannes C, Sothy M, San S, Bunthon C, Davun H, Dirk Van A, Jozef V. 2011. Infections with gastrointestinal nematodes, Fasciola and Paramphistomum in cattle in Cambodia and their association with morbidity parameters. Res Vet Sci.175: 293299.

Hasinah H, Handiwirawan E. 2006. Keragamanganetikternakkerbau di Indonesia. Lokakarya Nasional Usaha TernakKerbauMendukung Program KecukupanDagingSapi. Bogor (ID): Pusat Penelitian dan PengembanganPeternakan. hlm 89-95.

Levine ND. 1994. Buku Pelajaran ParasitologiVeteriner. Gatut Ashadi, penerjemah. Yogyakarta: Gajah Mada University Press. Terjemahandari:

TextbookofVeterinaryParasitolog y. USA: Burgess Publishing Company.

Padondan, A. T. 2016. Infeksi Cacing Nematoda Gastrointestinal pada Kerbau di Kabupaten Toraja Utara, Sulawesi Selatan.Skripsi, FakultasKedokteranHewanInstitut Pertanian Bogor, Bogor, p 10.

Rian. 2014. Toxocarosis pada SapiPotongPeternakan Rakyat di Kecamatan Ujung Jaya,
Sumedang.FakultasKedokteranHe wanInstitutPertanian Bogor.

Selvin S. 2004. Statistical Analysis of Epidemiology Data. London (GB): Oxford University Press.

Sriasih, M., Oscar Y, Dahlanuddin, William E. P. 2018. Gastrointestinal Parasite Infection on Bali Cattle Raised in SemiIntensive Farming System in Dompu, Sumbawa Island: $A$ Preliminary Study. International Journal of Bioscience and Biotechnology, 6 (1): 1-9.

Soulsby, E.J.L. 1982. Helminths, Arthropods and Protozoa of Domesticated Animal. Edisi Ketujuh. Baillere Tindall. London.

Tarmudji. 1990. BeberapaPenyakitPenting pada Kerbau di Indonesia. BalaiPenelitianVeteriner. Bogor

Thienpont, D., Rochette, F., Vanparijs, O.F.J. $\quad 1995 . \quad$ Diagnosing Helminthiasis Through Coprological Examination, Appleton - Century - Crofts, United State of America, 181 hal.)

Tolistiawaty I., Widjaja J., Lobo L.T dan Isnawati R. 2016. Parasit Gastrointestinal pada HewanTernak di Tempat Pemotongan Hewan Kabupaten Sigi, Sulawesi Tengah. Balai Litbang P2B2. Donggala.

Ulum, R. A. N. 2017. Identifikasi Eimeria Spp. Pada Kerbau Dan Sapi di Daerah Ciapus Bogor. FakultasKedokteranHewanInstitut Pertanian Bogor Bogor.

Whitlock. 1980.Universal Egg Counting Technique. Veterinary Parasitology. 7: 215. 
Jurnal Ilmu dan Teknologi Peternakan Indonesia Volume 6 (1) 39 - 50; Juni 2020

p-ISSN: 2460-6669 e- ISSN: 2656-4645

Zulfikar. 2012. Derajat InfestasiParasit Nematoda Gastrointestinal Pada Sapi di Aceh Bagian Tengah. Aceh: Universitas Syiah Kuala. 